\title{
PENGARUH FLAVONOID EKSTRAK MAHKOTA DEWA (PHALERIA MACROCARPA) TERHADAP PENINGKATAN INDEKS APOPTOSIS PADA PERITONEAL MENCIT MODEL ENDOMETRIOSIS
}

\author{
Maharani ${ }^{*}$, Sutrisno ${ }^{2}$ \\ 1Jurusan Kebidanan Poltekkes Kemenkes Aceh \\ 2Divisi Fertilitas Endokrinologi Reproduksi Departemen Obstetri dan Ginekologi Fakultas Kedokteran Universitas \\ Brawijaya / Rumah Sakit Umum Dr. Saiful Anwar Malang \\ *Korespondensi e-mail: maharani@poltekkesaceh.ac.id
}

\section{ABSTRACT EFFECT OF FLAVONOID EXTRACT FROM MAHKOTA DEWA (PHALERIA MACROCARPA) ON INCREASING CELL APOPTOTIC INDEX IN PERITONEAL ENDOMETRIOSIS MICE MODEL}

Background: Endometriosis is one of the main reproductive problems today because the incidence is quite high. The development and progression of endometriosis cells results from an abnormal balance between cell proliferation and apoptosis. Cell apoptosis is triggered by an imbalance between positive signals (cell growth factors) and negative signals (DNA damage) in endometriosis. The anti-cancer effect of Mahkota Dewa has been shown to suppress cancer growth and inhibit cancer cell invasion through inhibition of proliferation and antiapoptotic activity,

Purpose: This study aimed to determine the effect of giving flavonoid extract from Mahkota Dewa fruit on the apoptotic index in endometriosis model mice.

Methods: This research is an experimental study conducted at the Laboratory of the Faculty of Veterinary Medicine, Airlangga University, Surabaya. The sample used mice (Mus musculus) endometriosis model. The study was divided into 6 groups: negative control, positive control and treatment with the flavonoid extract of the Mahkota Dewa fruit at a dose of $3.75 \mathrm{mg} /$ day, $7.5 \mathrm{mg} /$ day, $11.25 \mathrm{mg} /$ day and $15 \mathrm{mg} /$ day. Measurement of apoptotic index using Tunel kit immunohistochemistry. Obsenvational data were analyzed by ANOVA dan Tukey. Results: There was significant difference in the mean apoptotic index of the five groups of observational samples, the mean value of the apoptotic index was found between the KP group $(7.96 \pm 1.02)$ and the group given flavonoid extract from the Mahkota Dewa fruit group P1 at a dose of $3.75 \mathrm{mg}(5.36 \pm 0.91), P 2$ dose $7.5 \mathrm{mg}(3.4$ $\pm 0.49), P 3$ dose $11.25 \mathrm{mg}(3.88 \pm 0.59)$, P4 dose $15 \mathrm{mg}$ (3.96 \pm 0.75$)$.

Conclusion: The administration of flavonoid extract of the Mahkota Dewa fruit had a significant effect on increasing cell apoptotic index in endometriosis model mice.

Suggestion Further study is needed to see the effect of flavonoid extract of Mahkota Dewa on rabbit experimental animals.

Keywords: endometriosis, flavonoid extract of Mahkota Dewa fruit, apoptotic index

\section{ABSTRAK}

Latar Belakang: Endometriosis menjadi salah satu masalah reproduksi utama saat ini karena angka kejadian cukup tinggi. Perkembangan dan progresi sel endometriosis akibat terjadinya abnormalitas keseimbangan antara proliferasi dan apoptosis sel. Apoptosis sel dipicu karena adanya ketidakseimbangan antara sinyal positif (faktor pertumbuhan sel) dan sinyal negatif (kerusakan DNA) pada kondisi endometriosis. Efek anti kanker mahkota dewa terbukti dapat menekan pertumbuhan kanker dan menghambat terjadinya invasi sel kanker melalui penghambatan aktivitas proliferasi dan anti apoptosis.

Tujuan: Penelitian ini bertujuan untuk mengetahui efek pemberian flavonoid ekstrak dari buah mahkota dewa terhadap indeks apoptosis pada mencit model endometriosis.

Metode: Penelitian ini merupakan penelitian eksperimental yang dilakukan di Laboratorium Fakultas Kedokteran Hewan Universitas Airlangga Surabaya. Sampel menggunakan mencit (Mus musculus) model endometriosis. Penelitian dibagi menjadi 6 kelompok, yaitu : kontrol negatif, kontrol positif dan perlakuan pemberian ekstrak flavonoid buah mahkota dewa dosis $3,75 \mathrm{mg} / \mathrm{hari,}, 7,5 \mathrm{mg} / \mathrm{hari}, 11,25 \mathrm{mg} / \mathrm{hari}$ dan15 mg/hari. Pengukuran indeks apoptosis menggunakan imunohistokimia Tunel kit. Data hasil pengamatan dianalisis dengan 


\section{JKM (Jurnal Kebidanan Malahayati),Vol 7,No.4.Oktober 2021, ISSN (Print) 2476-8944 ISSN (Online) 2579-762X, Hal 652-657}

uji ANOVA dan Tukey. Uji statistik dikatakan bermakna bila $p<0,05$.Proses penghitungan dilakukan dengan bantuan piranti lunak (soft-ware) SPSS for windows 19.0.

Hasil: Terdapat perbedaan yang bermakna rerata indeks apoptosis kelima kelompok sampel pengamatan didapatkan nilai rerata indeks apoptosis antara kelompok K- $(7.96 \pm 1.02)$ dengan kelompok pemberian ekstrak flavonoid dari buah mahkota dewa kelompok P1 dosis $3,75 \mathrm{mg}(5.36 \pm 0.91)$, P2 dosis $7,5 \mathrm{mg}(3.4 \pm 0.49)$, P3 dosis $11,25 \mathrm{mg}(3.88 \pm 0.59)$, P4 dosis $15 \mathrm{mg}(3.96 \pm 0.75)$.

Kesimpulan: Pemberian ekstrak flavonoid buah mahkota dewa memberikan pengaruh yang signifikan terhadap peningkatan indeks apoptosis sel pada mencit model endometriosis.

Saran Perlu studi lanjut untuk melihat pengaruh flavonoid ekstrak mahkota dewa pada hewan coba kelinci.

Kata Kunci: endometriosis, flavonoid ekstrak buah mahkota dewa, indeks apoptosis

\section{PENDAHULUAN}

Endometriosis merupakan penyakit tumor jinak yang memiliki kharakteristik keganasan seperti pada kanker (Leyland et al., 2010). Penyakit ini menjadi salah satu masalah reproduksi utama saat ini karena angka kejadian cukup tinggi. Ditemukan 1 dari 10 wanita usia reproduktif (15-49 tahun) atau sekitar 176 juta wanita di seluruh dunia terinfeksi penyakit ini. Berbagai keluhan dialami penderita endometriosis yaitu dismenorea, dispareunia, disuria, nyeri kronik abdomen, nyeri pelvik dan nyeri waktu defekasi (Burney and Giudice, 2012). Lebih lanjut dampak yang ditimbulkan meningkatkan kejadian resiko kanker ovarium dan infertilitas. Apabila tidak mendapatkan pengobatan yang tepat maka dampak dan progesivitas endometriosis terus berjalan sepanjang kehidupan seorang wanita.

Perkembangan dan progresi sel endometriosis akibat terjadinya abnormalitas keseimbangan antara proliferasi dan apoptosis sel (Awwad et al., 2012). Peningkatan proliferasi menunjukkan terjadinya peningkatan keganasan sedangkan penurunan apoptosis menunjukkan adanya kegagalan lokal dalam mekanisme melawan perkembangan kanker dan menunjukkan terjadinya peningkatan metastase. Apoptosis sel dipicu karena adanya ketidakseimbangan antara sinyal positif (faktor pertumbuhan sel) dan sinyal negatif (kerusakan DNA) pada kondisi endometriosis (Nasu et al., 2011). Aktivitas proliferasi dan apoptosis sel endometriosis tersebut distimulir oleh estrogen akibat peningkatan aktivasi abnormal proses steroidogenesis yang melibatkan aromatase (Bulun, 2009; Fassbender et al., 2014). Produksi estrogen lokal secara terus menerus pada jaringan endometriosis menginduksi aktivitas proliferasi dan menghambat proses apoptosis sel.

Terapi endometriosis meliputi pembedahan dan medikamentosa. Terapi tersebut memiliki banyak kekurangan diantaranya mahal, hanya bersifat menghilangkan nyeri dan pengobatan dilakukan secara terus menerus dikarenakan endometriosis dapat kambuh kembali (Awwad et al., 2012). Dibutuhkan terapi herbal berasal dari tanaman yang bersifat alami, harga lebih murah karena dapat dibudidayakan, mudah didapat dan diharapkan efek samping lebih minimal dibanding obat antikanker sintetik.

Saat ini jenis tanaman herbal telah banyak dilakukan penelitian untuk mengobati berbagai keluhan dan terapi pada kanker termasuk endometriosis. Mahkota Dewa (Phaleria macrocarpa) merupakan salah satu tanaman herbal untuk terapi antikanker melalui penghambatan proliferasi sel dan induksi (Amit et al., 2001; Lisdawati, 2009). Mahkota dewa (Phaleria macrocarpa) memiliki kemampuan menghambat pertumbuhan tumor primer, meregulasi proses metastasis, termasuk adhesi sel, migrasi dan invasi. Berbagai penelitian telah dilakukan, studi in vitro efek anti kanker mahkota dewa (Phaleria macrocarpa) diujikan terhadap sel kanker terbukti dapat menekan pertumbuhan kanker menunjukkan aktivitas biologi antikanker, mampu menghambat terjadinya invasi sel kanker tersebut melalui penghambatan aktivitas proliferasi dan anti apoptosis (Riastiti, 2004; Lisdawati, 2002).

Kandungan kimia pada tanaman mahkota dewa mulai dari buah, biji, daun dan kulit buah mengandung alkaloid, terpenoid, polifenol, saponin, resin, lignan dan flavonoid.Alkaloid adalah senyawa organik berfungsi sebagai detoksifikasi, menetralisir racun-racun di dalam tubuh. Saponin adalah fitonutrien bersifat antibakteri dan antivirus yang dapat meningkatkan sistem kekebalan tubuh, meningkatkan daya tahan, mengurangi kadar gula darah dan mengurangi penggumpalan darah. Flavonoid sebagai antiperadangan dan mencegah pertumbuhan sel kanker, sedangkan polifenol berfungsi sebagai antihistamin. Selain itu, tanaman tersebut juga digunakan untuk mengobati penyakit lever, kanker dan tekanan darah tinggi (Winarto, 
2005; Lisdawati, 2002). Seluruh golongan ini memiliki senyawa dengan struktur molekul spesifik dan telah terbukti bekerja sebagai derivate antikanker melalui mekanisme selular proapoptosis dan antiproliferasi pada sel kanker.

Penelitian yang dilakukan oleh Kurnia $d k k$. (2005) membuktikan bahwa ekstrak buah mahkota dewa memiliki efek penghambatan pada sel kanker leukemia THP-1. Studi in vivo pada mencit $\mathrm{C} 3 \mathrm{H}$ yang ditransplantasi tumor payudara, pemberian ekstrak etanol daging buah mahkota dewa dengan dosis $20,40,80$ kali dosis manusia selama 30 hari menunjukkan tidak menghambat pertumbuhan tumor namun terjadi peningkatan apoptosis secara bermakna pada dosis 80 kali dosis manusia. Dari penelitian ini belum menjelaskan dosis yang paling ideal untuk digunakan sebagai terapi sehingga perlu dilihat pemberian berbagai dosis ekstrak buah mahkota dewa khususnya pada endometriosis.

Menurut penelitian Arini dkk. (2003) diketahui bahwa daging buah mahkota dewa mengandung flavonoid. Ekstrak etanol $70 \%$ daging buah mahkota dewa mempunyai kadar relatif flavonoid yang paling besar $(45,734 \mu \mathrm{g} / \mathrm{mg})$. Mekanisme kerja ekstrak buah mahkota dewa belum diketahui secara jelas namun berdasarkan beberapa referensi diduga melalui down regulasi ekspresi pro-inflammatory cytokine kemudian memblokir aktivasi factor transkripsi (Nf-kB) yang selanjutnya menghambat sintesis DNA menjadi mRNA dan menurunkan produksi sintesis gen-gen target, menginduksi jalur apotosis melalui peningkatan sintesa protein proapoptosis mengakibatkan proliferasi sel endometriosis menjadi terhambat.

Berdasarkan beberapa penelitian yang telah dilakukan pentingnya peran mahkota dewa sebagai antikanker dan melihat masih terbatasnya penelitian pengaruh ekstrak buah mahkota dewa pada endometriosis, maka penulis meneliti tentang "efek flavonoid ekstrak mahkota dewa terhadap indeks apoptosis pada peritoneal mencit (Mus musculus) model endometriosis". Diharapkan melalui induksi apoptosis, proliferasi sel endometriosis menjadi dapat terhambat.

\section{METODE PENELITIAN}

Penelitian ini menggunakan desain eksperimental, Post test only with control group, dilakukan di Laboratorium Fakultas Kedokteran Hewan Universitas Airlangga Surabaya. Sampel yang dipergunakan adalah mencit (Mus musculus) betina model endometriosis. Jumlah replikasi sebanyak 6 replikasi dengan 1 kelompok kontrol negatif, 1 kontrol positif dan 4 kelompok dengan perlakuan yaitu $3,75 \mathrm{mg} / \mathrm{hari}, 7,5 \mathrm{mg} / \mathrm{hari}, 11,25$ $\mathrm{mg} /$ hari dan15 mg/hari.

Alat yang digunakan meliputi seperangkat alat bedah steril, timbangan analitik, sonde, pengaduk, gelas ukur, spuit, tabung, camera digital, Micro Sentrifuge Tube 1,5 ml, pipet mikro $50 \mu \mathrm{L}$, $100 \mu \mathrm{L}$ dan $1000 \mu \mathrm{L}$, tip falcon $15 \mathrm{ml}$, Sentrifuge, serta Tunel Kit.

\section{Prosedur Pembuatan Mencit (Mus musculus) Model Endometriosis}

Pembuatan mencit model endometriosis merujuk pada penelitian Sutrisno (2014). Pada hari pertama mencit (Mus musculus) pada kelompok K+ dan perlakuan diberikan injeksi Syclosporin A 0,2 ml IM, penyuntikan jaringan endometrium dan myometrium dari bahan operasi tumor jinak (adenomyosis) 0,1 ml IP. Penyuntikan Ethynil Estradiol 0,1 ml IM pada hari ke 1 dan 5. Kemudian ditunggu selama 14 hari, didapatkan mencit sebagai model endometriosis.

\section{Prosedur Pemberian Ekstrak Flavonoid Buah Mahkota Dewa Berbagai Dosis}

Kelompok perlakuan dipapar berbagai dosis flavonoid ekstrak buah mahkota dewa dengan dosis $3,75 \mathrm{mg} / \mathrm{hari}, 7,5 \mathrm{mg} / \mathrm{hari}, 11,25 \mathrm{mg} / \mathrm{hari}$, dan 15 $\mathrm{mg} /$ hariselama 14 hari.

\section{Prosedur Pengukuran Indeks Apoptosis dengan metode imunohistokimia Tunel Kit}

Slide dari jaringan hipokampus dibersihkan dari media dengan buffer hepes atau PBS dingin sebanyak 3 kali. Slide difiksasi dengan metanol absolute selama 3-5 menit, dikering-anginkan. Diinkubasi pada blocking reagen FBS 10\% dalam PBS 30-60 menit. Dicuci dengan PBS dingin 5 menit, 3 kali. Diinkubasi menggunakan antibodi primer dalam 1-2\% blocking reagen selama 2 jam pada suhu ruangan atau overnight pada $4^{\circ} \mathrm{C}$. Dicuci dengan PBS dingin 5 menit, 3 kali. Diinkubasi dengan fluorescein-conjugeted secondary antibody dalam $1 \%$ - $2 \%$ blocking reagent selama 1 jam pada RT. Ditutup dengan coverslip yang diberi entelan. Sel diamati dengan mikroskop dengan pembesaran 400 kali.

\section{HASIL DAN PEMBAHASAN}

Pada hari ke 29 dilakukan terminasi untuk diambil jaringan peritoneal mencit (Mus musculus) dan kemudian diukur indeks apoptosis dengan metode Tunel. Gambaran Indeks Apoptosis Pada Pemeriksaan Imunohistokimia ditunjukkan Gambar 1 

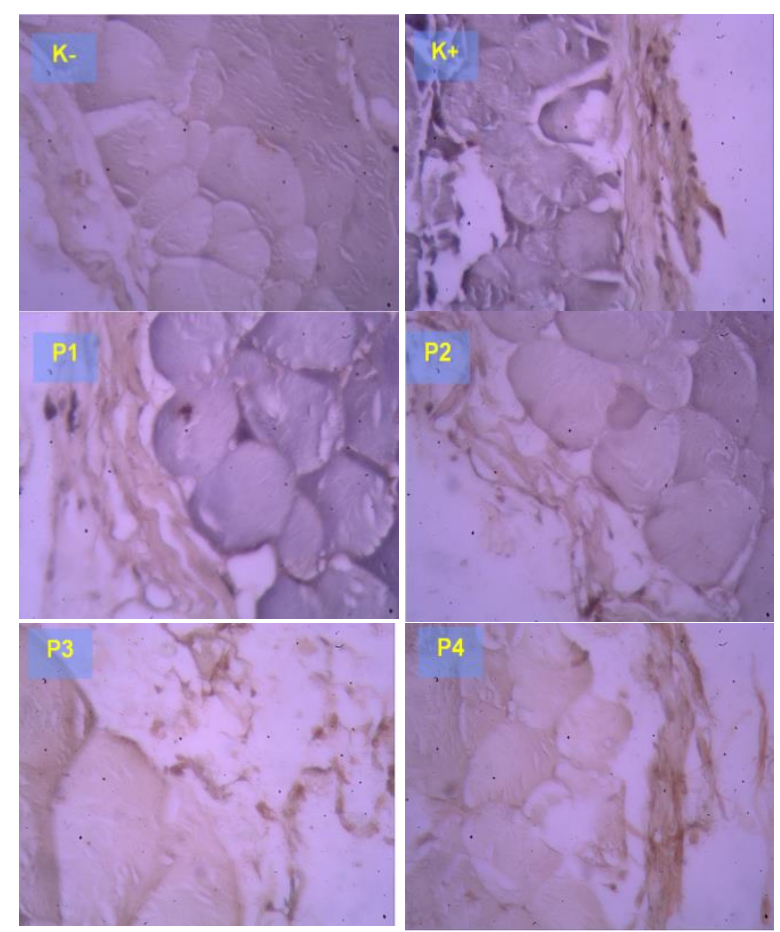

Gambar 1.

Histopatologi Perbedaan Apoptosis

Perbedaan apoptosis pada jaringan granulasi dengan warna coklat kromogen diantara kelompok perlakuan. Pada slide diatas nampak bahwa apoptosis paling kuat terjadi pada $\mathrm{K}+$ Dibandingkan kelompok perlakuan lainnya (pewarnaan immuno histokimia, Pembesaran 400x; mikroskop Nikon Eclips Ci; camera Optilab Advanced+ 12 megapixel)

Tabel 1.

Perbandingan Indeks apoptosis dengan ANOVA dan Uji Tukey $5 \%$

\begin{tabular}{ccc}
\hline Perlakuan & Mean \pm SD & p-value \\
\hline K- & $2.16 \pm 0.46$ & \\
K+ & $7.96 \pm 1.02$ & \\
P1 & $5.36 \pm 0.91$ & 0.000 \\
P2 & $3.40 \pm 0.49$ & \\
P3 & $3.88 \pm 0.59$ & \\
P4 & $3.96 \pm 0.75$ & \\
\hline
\end{tabular}

Keteranagan : Pada rata-rata \pm sd jika memuat huruf yang berbeda berarti ada perbedaaan yang bermakna $(p<0.05)$ dan jika memuat huruf yang sama berarti tidak ada perbedaan yang bermakna $(p>0.05)$.

Berdasarkan pada hasil analisis Tabel 1 dengan menggunakan ANOVA, didapatkan $p$-value sebesar 0,000 . Sehingga dari pengujian ini dapat disimpulkan bahwa terdapat pengaruh yang signifikan pemberian ekstrak flavonoid dari buah mahkota dewa terhadap indeks apoptosis. Atau dengan kata lain, terdapat perbedaan yang signifikan indeks Apoptosis akibat pemberian ekstrak flavonoid dari buah mahkota dewa dengan dosis yang berbeda.

Berdasarkan pada hasil uji Tukey $5 \%$ pada Tabel 3 di atas, ditunjukkan bahwa kelompok kontrol negatif (K-) memiliki rata-rata indeks Apoptosis paling rendah yakni sebesar $2.16 \pm 0.46$ dan secara statistik berbeda signifikan dengan kelompok kontrol positif $(\mathrm{K}+)$. Hal ini ditunjukkan dari nilai rata-rata \pm sd pada kelompok K- dan K+ memuat huruf yang berbeda. Pemberian ekstrak flavonoid dari buah mahkota dewa pada kelompok P1, P2, P3, dan P4 menghasilkan indeks Apoptosis lebih rendah dari pada kelompok dan $\mathrm{K}+$. dari pengujian ini dibuktikan bahwa terjadi penurunan Indeks Apoptosis secara signifikan akibat pemberian ekstrak flavonoid dari buah mahkota dewa berbagai dosis.

Rata-rata indeks Apoptosis kelompok kontrol dan perlakuan secara lengkap ditunjukkan dalam histogram berikut :

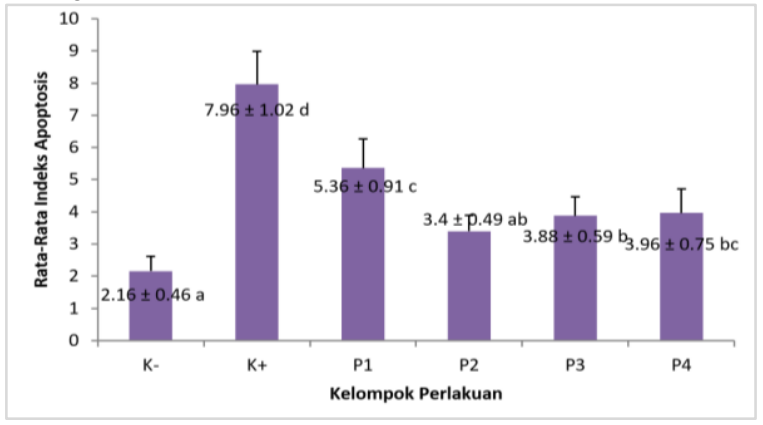

Gambar 2.

\section{Histogram Rata-Rata Indeks Apoptosis}

Pada Gambar 2 ditunjukkan histogram ratarata indeks Apoptosis semua kelompok kontrol dan perlakuan. Dimulai dari kelompok K-, terlihat bahwa rata-rata indeks Apoptosis meningkat pada kelompok K+. Kemudian, pada kelompok P1, P2, $\mathrm{P} 3$, dan $\mathrm{P} 4$ terjadi penurunan rata-rata indeks Apoptosis. Pada kelompok perlakuan, rata-rata indeks Apoptosis terendah terdapat pada kelompok P2. Dari pengujian ini, ditunjukkan bahwa kelompok P2 mampu menghasilkan indeks Apoptosis relatif sama dengan kelompok K-.

\section{PEMBAHASAN}

Endometriosis merupakan kelainan ginekologi yang jinak namun memiliki potensi keganasan. Peningkatan keganasan menunjukkan adanya kegagalan lokal dalam mekanisme melawan 
perkembangan kanker akibat dari penurunan proses apoptosis (Wiweko et al., 2013). Penelitian ini bertujuan untuk mengetahui efek pemberian ekstrak flavonoid dari buah mahkota dewa berbagai dosis yaitu $3,75 \mathrm{mg} / \mathrm{hari}, 7,5 \mathrm{mg} / \mathrm{hari}, 11,25 \mathrm{mg} /$ hari dan $15 \mathrm{mg} /$ hari terhadap penurunan indeks apoptosis sel pada mencit model endometriosis.

Arini dkk. (2003) menjelaskan bahwa daging buah mahkota dewa mengandung flavonoid. Ekstrak etanol $70 \%$ daging buah mahkota dewa mempunyai kadar relatif flavonoid yang paling besar $(45,734 \mu \mathrm{g} / \mathrm{mg})$. Mekanisme kerja ekstrak buah mahkota dewa belum diketahui secara jelas. Diduga metabolit sekunder yang terkandung didalamnya yang memicu aktivitas antikanker ekstrak buah mahkota dewa. Flavonoid merupakan salah satu senyawa bioaktif dan salah satu kelompok senyawa metabolit sekunder yang berpotensi sebagai antiperadangan dan mencegah pertumbuhan sel kanker melalui mekanisme selular proapoptosis dan antiproliferasi pada sel kanker.

Sebagian besar flavonoid telah terbukti mampu menghambat proliferasi pada berbagai sel kanker pada manusia namun bersifat tidak toksik pada sel normal manusia (Rahmawati et al., 2006). Penelitian yang dilakukan oleh Kurnia dkk. (2005) membuktikan bahwa ekstrak buah mahkota dewa memiliki efek penghambatan pada sel kanker leukemia THP-1. Hasil penelitian diketahui flavonoid mampu menginduksi terjadinya apoptosis. Mekanisme flavonoid dalam menginduksi terjadinya apoptosis melalui down regulasi ekspresi proinflammatory cytokine kemudian memblokir aktivasi factor transkripsi (Nf-kB) yang selanjutnya menghambat aktivitas DNA topoisomerase I/II, modulasi signalling pathways, penurunan ekspresi gen $\mathrm{Bcl}-2$ dan $\mathrm{Bcl}-\mathrm{XL}$, peningkatan ekspresi gen Bax dan Bak, serta aktivasi endonuclease. Flavonoid menghambat ekspresi enzim topoisomerase I dan topoisomerase II yang berperan dalam katalisis pemutaran dan relaksasi DNA. Topoisomerase merupakan suatu enzim yang berfungsi memotong DNA yang berlilitan ketat akibat pembukaan double strand DNA oleh enzim helikase, memutar balik dan kemudian menyambungkan lagi. Enzim tersebut bekerja pada saat perpanjangan replikasi DNA. Inhibitor enzim topoisomerase akan menstabilkan kompleks topoisomerase dan menyebabkan DNA terpotong dan mengalami kerusakan. Kerusakan DNA dapat menurunkan produksi sintesis gen-gen target, menginduksi jalur apotosis melalui peningkatan sintesa protein pro-apoptosis seperti Bax dan Bak dan menurunkan ekspresi protein antiapoptosis yaitu $B c l-2$ dan $B c / X L$, mengakibatkan pertumbuhan sel kanker terhambat.

\section{SIMPULAN}

Pemberian flavonoid ekstrak buah mahkota dewa berpengaruh secara signifikan terhadap peningkatan indeks apoptosis pada mencit model endometriosis.

\section{SARAN}

Perlu studi lanjut untuk melihat pengaruh flavonoid ekstrak mahkota dewa pada hewan coba kelinci.

\section{DAFTAR PUSTAKA}

Awwad, J. T. et al. (2012) 'NIH Public Access', Fertility and Sterility. Edited by L. Poresty. New York: Elsevier Inc., 2(1), pp. 1-9. doi: 10.1007/s00726-010-0689-X.

Bulun, S. E. (2009) 'Endometriosis. Mechanisms of disease', The New England Journal of Medicine. doi: 10.1177/1461444810365020.

Burney, R. O. and Giudice, L. C. (2012) 'Pathogenesis and pathophysiology of endometriosis', Fertility and Sterility. Elsevier Inc., 98(3), pp. 511-519. doi: 10.1016/j.fertnstert.2012.06.029.

Fassbender, A. et al. (2014) 'Biomarkers of endometriosis', Endometriosis: Pathogenesis and Treatment. Elsevier Inc., 99(4), pp. 321339. doi: 10.1007/978-4-431-54421-0_20.

Leyland, N. et al. (2010) 'Endometriosis: Diagnosis and Management', Journal of Obstetrics and Gynaecology Canada, 32(7), pp. S1-S3. doi: 10.1016/S1701-2163(16)34589-3.

Nasu, K. et al. (2011) 'Aberrant expression of apoptosis-related molecules in endometriosis: A possible mechanism underlying the pathogenesis of endometriosis', Reproductive Sciences. doi: 10.1177/1933719110392059.

Amit, KT., Madhumita, R., Bhattacharya, RK. 2001. Natural products as inducer of apoptosis: Impication for cancer therapy and prevention. Current Science. 80 (11) : 138796

Lisdawati, V. 2002. Mahkota Dewa, toksisitas, efek antioksidan dan efek antikanker berdasarkan uji penapisan farmakologi. Jakarta (INA): PT Phaleria macrocarpa

Riastiti. 2004. Pengaruh Ekstrak Etanol Biji Buah Mahkota Dewa (Phaleria macrocarpa) terhadap Proliferasi dan Apoptosis Sel Ca 
JKM (Jurnal Kebidanan Malahayati),Vol 7,No.4.Oktober 2021,

ISSN (Print) 2476-8944 ISSN (Online) 2579-762X, Hal 652-657

Colon, Program Pasca

Sarjana:UniversitasGadjah Mada, Yogyakarta

Winarto, W.P. dan Tim Karyasari. 2005. Budi Daya Dan Pemanfaatan Mahkota Dewa Untuk Obat. Penebar Swadaya. Jakarta

Kurnia, A., Pertamawati, R., dan Hendig. 2005. Efek Penghambat Petumbuhan Cell-Line THP-1 Secara In Vitro dari Ekstrak Etanol Buah Mahkota Dewa (Phaleria macrocarpa Scheff.). Jurnal Artocarpus.5 (2): 89-94

Arini, S., Dani, N., Fin, A., dan Triana, H. 2003. Daya Antioksidan dan Kadar Flavonoid Hasil Ekstraksi Etanol Air Daging Buah Mahkota Dewa (Phaleria macrocarpa [Scheff.] Boerl.). Jurnal Fakultas Farmasi. UGM. Jogjakarta

Sutrisno. 2014. Pengaruh Asal Implant Terhadap Kejadian Peritoneal Endometriosis, Studi Untuk Mendesain Mencit Model
Endometriosis. Laboratorium Obstetri dan Ginekologi FK Universitas Brawijaya, Malang Wiweko, B., Puspita, C., Sumapraja, K., Natadisastra, M., Harzief, AK., Situmorang, H., Pratama, G., Hestiantoro, A. 2013. DLBS14442: Pilihan Penanganan Terkini pada Endometriosis. Medicinus. 26: 2-4

Arini, S., Dani, N., Fin, A., dan Triana, H. 2003. Daya Antioksidan dan Kadar Flavonoid Hasil Ekstraksi Etanol Air Daging Buah Mahkota Dewa (Phaleria macrocarpa [Scheff.] Boerl.). Jurnal Fakultas Farmasi. UGM. Jogjakarta

Rahmawati, E., Dewoto, HR., Wuyung PE. 2006. Anticancer Activity Study of Ethanol Extract of Mahkota Dewa Fruit Pulp (Phaleria Macrocarpa [Scheff.] Boerl.) in C3H Mouse Mammary Tumor Induced by Transplantation. Medical Journal of Indonesia. 15 (4): 217-222 